\title{
Fetal MRI in Management of Complicated Meconium Ileus: Prenatal and Surgical Imaging
}

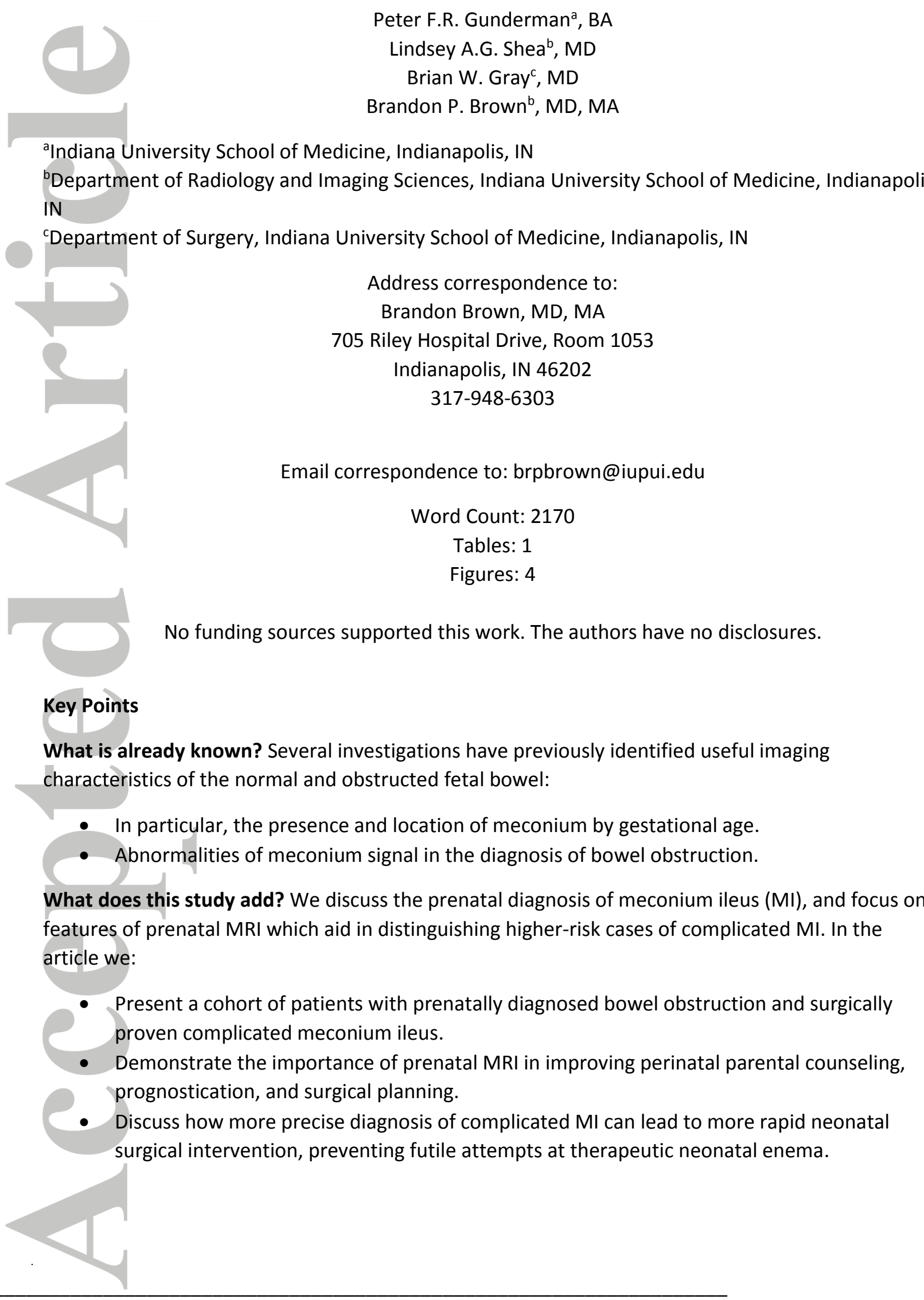

This is the author's manuscript of the article published in final edited form as: 


\section{Abstract}

Objective: To review fetal MRI cases surgically proven to have MI and obstruction, describe the common fetal MRI findings that distinguish cases of complicated $\mathrm{MI}$, and to compare these findings with surgical images and perinatal outcomes.

Method: We performed a retrospective review of all fetal MRI examinations and the corresponding medical record from our tertiary care children's hospital over an 18 month period. Postnatal management and outcomes were reviewed for these patients, and those patients with surgical or postmortem diagnosis of complicated MI were included in the study.

Results: Our analysis revealed seven cases. In this cohort, three imaging features of the fetal bowel were repeatedly seen: gradient appearance of intraluminal bowel contents, abnormally localized meconium signal, and collapsed appearance of the colon on MRI. Surgical diagnoses confirmed MI. All live-born infants underwent surgical repair.

Conclusion: Fetal MRI should be included in the diagnostic algorithm of any pregnancy where fetal bowel obstruction is suspected, in order to better risk stratify patients.

\section{Introduction}

Meconium ileus (MI), often associated with cystic fibrosis (CF), is defined as an obstruction at the terminal ileum caused by impaction of abnormally viscous meconium, with resulting impaired intestinal motility and functional obstruction. (1) Cases of $\mathrm{MI}$ in which additional bowel abnormalities such as atresia, volvulus, or perforation have arisen are here described as "complicated MI" (see Figure 1). While once thought to be almost pathognomonic of CF, recent studies have demonstrated the surprisingly high prevalence of meconium ileus without positive CF testing. (2-5) For the subset of patients with complicated $\mathrm{MI}$, the relationship to CF becomes even less clear as the incidence of complications arising from MI may be even higher in patients without CF. (3)

In either population, the accurate distinction between isolated and complicated $\mathrm{MI}$ is critical in determining the prognosis, degree of intervention, and most appropriate timing of treatment. While isolated meconium ileus is sometimes able to be non-surgically managed in the neonatal period with one or more contrast enema studies which have been demonstrated to be capable of a therapeutic as well as diagnostic function, surgical intervention is necessary for those complicated cases with concurrent volvulus or atresia. (6) For these complex cases, performing repeated contrast enema studies with a therapeutic intent will have no benefit, and could even cause harm through delay in surgical management.

Prenatal ultrasonography has proven to be reliable in recognizing signs of bowel dilation and suspected obstruction. (7) However, ultrasound can be limited in its ability to determine the etiology and extent of bowel abnormalities, depending on the level of expertise of the operator. (8-12) Fetal MR imaging, with its extended field of view, ability to more specifically identify the intraluminal bowel contents, and high resolution imaging of the intraperitoneal space is particularly adept at identifying those cases at high risk for associated complication. (11,13-15) MR imaging during pregnancy is increasingly recognized as a safe and valuable method of characterizing fetal anatomy

This article is protected by copyright. All rights reserved. 
and pathology, $(8,16,17)$ with a recent large-scale retrospective study finding no increased risk of harm to the fetus even in first trimester MRI. (18)

The basic characteristics of the normal fetal GI tract as depicted on MRI have been well-established in the literature, and while constantly evolving, the optimal MR pulse sequences for fetal GI imaging have also been described. (19-23) The surge of recent literature on fetal MRI has now provided an opportunity for practitioners to further characterize particular fetal gastrointestinal abnormalities and even correlate these prenatal diagnoses with postnatal surgical and pathological findings.

Several researchers have identified useful imaging characteristics of the fetal bowel, and in particular the presence and location of meconium, in the diagnosis of $\mathrm{Gl}$ abnormalities. More recent investigations have also discussed the MR signs of small bowel obstruction. (24-27). However, the existing literature has little discussion of how and why to risk-stratify isolated MI from those higherrisk cases of complicated MI. The present study analyzes a cohort of patients with prenatally diagnosed (and later confirmed) complicated meconium ileus and correlates the imaging appearance with surgical findings. We demonstrate the role of fetal MRI in the prenatal diagnosis of this condition, with the goal of improving perinatal parental counseling, prognostication, and surgical planning.

\section{Methods}

This study was approved by the institute review board at our hospital, and patient written consent was waived for this retrospective study. A retrospective review of recent fetal MR imaging examinations and the corresponding US imaging report and medical record from our tertiary care children's hospital was performed, including all cases over the 18 month period from January 2015 to August 2017. Each infant's postnatal course, operative reports, and laboratory testing were reviewed. All prenatal MR imaging was re-evaluated for specific features of high-grade obstruction by a pediatric radiologist with 5 years expertise in prenatal diagnosis. Postnatal management and outcomes were reviewed for these patients, and those patients with surgical or postmortem diagnosis of complicated meconium ileus were included in the study. For the fetal MR exams, images were obtained using a 3T MRI scanner with 18-channel body surface coil and integrated spine matrix coil (MAGNETOM Skyra; Siemens, Erlangen, Germany). The MR imaging used our routine fetal imaging protocol which evaluates fetal brain, fetal body, uterus, and placenta. We utilize pulse sequences optimized for faster acquisition times, including a combination of 3- to 4-mm half-Fourier single-shot fast spin echo with T2-weighting (T2-weighted SSFSE; "HASTE") in three planes, steadystate free precession in three planes (SSFP; “TruFISP"), T1-weighted fast spoiled gradient echo breath-hold in three planes (T1-W GRE; "VIBE"), and gradient echo in axial plane (multi-echo spoiled T2*-weighted GRE; "MEDIC"). The MR imaging was performed within one week of prenatal US for all cases. US images were obtained by the Maternal-Fetal Medicine specialist using a Voluson E8 (GE Healthcare, Milwaukee, WI).

This article is protected by copyright. All rights reserved. 


\section{Results}

Seven cases of prenatal MR imaging of complicated meconium ileus were identified for review. The MR exams were performed between 25 and 37 weeks gestational age. For each case, gestational age at MRI, prenatal imaging diagnosis, CFTR mutation status, gestational age at birth, delivery type, Apgar score, length of neonatal hospital stay, type of neonatal surgical repair, surgical diagnosis, and pathologic diagnosis, and ultimate disposition are discussed below and summarized in Table 1.

Three common findings suggestive of complicated meconium ileus were identified among the cases presented below. These findings are:

1. The appearance of a gradient of fluid-fluid and fluid-solid layering contents of the intraluminal small bowel evidenced by a transition from a relatively hypointense signal into a more hyperintense appearance similar to amniotic fluid within a single loop of dilated bowel. (Figures 1, 3, and 4)

2. An abnormally focal and localized meconium signal with abrupt truncation secondary to the obstruction. (Figure 1, 2, and 4)

3. The appearance of a so-called "microcolon," for which the colon appears collapsed and demonstrates a paucity of meconium signal, unlike the bright T1 signal of the healthy fetal colon. (Figures 1 and 2)

These findings are described in the cases outlined in Table 1, and further defined in the discussion. Images of the findings in particular cases can be seen in the accompanying figures.

\section{Discussion}

One of the key objectives of the present study was to clarify the specific features of fetal MRI that would lead to increased suspicion for complicated MI. While the comparison of prenatal imaging and postnatal findings within our cohort demonstrates that fetal MRI cannot always provide diagnostic certainty, we identified three consistent features in our analysis of the MR studies for the seven cases within our cohort.

One feature was the appearance of a gradient of fluid-fluid and fluid-solid layering contents of the intraluminal small bowel. There was a transition from a relatively hypointense signal into a more hyperintense appearance similar to amniotic fluid within a single loop of dilated bowel. We hypothesize that this represents an organization of static intraluminal contents resulting from the complete bowel obstruction that is always a part of complicated meconium ileus.

A second feature was abnormally focal and localized meconium signal. As has been well described, meconium typically demonstrates high signal intensity on T1-weight images due to its high protein and paramagnetic material content (copper, iron, and manganese). $(24,26)$ That the bright signal of meconium on T1-weighted imaging becomes more conspicuous with increasing gestational age has also previously been demonstrated. (28) In cases of complicated meconium ileus, the hyperintense meconium signal is not normally distributed throughout the bowel according to gestational age, but rather stops abruptly at the level of obstruction, or can be seen trapped within a closed loop, such as in cases of volvulus. (Figure 2 ) In cases of perforation, meconium signal can be seen within ascites fluid, as focal nodules against the abdominal wall, or collected within a pseudocyst. 
Distal to the obstruction is a third common MR feature of MI, which is the MR appearance of a microcolon. The colon appears collapsed and demonstrates a paucity of meconium signal, unlike the healthy fetal colon, which generally displays bright T1 signal after $21-24$ weeks gestation. $(26,28)$ This correlates well with the postnatal fluoroscopic enema appearance of a microcolon, which is classically associated with meconium ileus. While this finding in isolation can be seen with both complicated and non-complicated meconium ileus, when combined with either of the other two characteristic findings in our cohort it added to the diagnostic confidence.

For prenatal care, the more refined diagnosis suggested by these imaging characteristics can provide several benefits. First, it can assist with family counseling, which is a somewhat unique goal in prenatal diagnosis, and distinct from the more frequently discussed goals of diagnosis and treatment planning. By providing a more refined prognosis, the care team can better prepare parents for what they will encounter in the perinatal period. Greater accuracy in prenatal parental counseling may not have any effect on neonatal outcomes; however, it can make a significant difference in the lives of the families who are affected.

A second benefit to a more refined diagnosis of complicated meconium ileus is that unnecessary postnatal studies and interventions can be avoided. For isolated meconium ileus, there is support in the literature for attempts at non-surgical reduction, through the use of hypertonic contrast during a fluoroscopic enema, and this has shown success up to $50 \%$ of the time. However, complicated cases involving atresia or volvulus must be managed surgically. $(6,30,31)$ In cases of fetal GI abnormalities requiring surgery, research has already shown that prenatal diagnosis results in earlier surgical intervention and fewer complications. $(32,33)$

Consider case 4 in the cohort presented here, which is a particularly clear example of the benefits of a streamlined diagnostic process. A diagnosis of complicated meconium ileus with suspected volvulus was made on prenatal MRI. Given the clear presence of imaging signs described above, the neonatal and surgical care teams decided to forgo additional postnatal diagnostic testing, such as abdominal radiographs or contrast enemas. Surgeons were able to operate at day 1 of life, and discovered meconium ileus, volvulus, and a tiny, contained perforation. However, of particular importance, there were also several segments of bowel that were adjacent to the volvulus and were identified as ischemic but not yet necrotic. Reduction and resection of the volvulus and repair of the perforation were performed, but the ischemic segments of bowel were preserved, and ultimately salvaged. It was noted in the surgical report that more delayed intervention would not have allowed salvage of the "at-risk" bowel. Thus, timely and accurate prenatal diagnosis was able to affect surgical timing and ultimately the patient's outcome.

This study had several limitations, including its retrospective nature, the relatively small cohort size, and the lack of a comparison cohort with prenatal care but no fetal MRI. An additional limitation was the lack of expert US imaging in some of the cases. Subsequent prospective study with a larger cohort and a control group will be helpful to further evaluate the effect of prenatal MR imaging on postnatal outcomes in cases of MI.

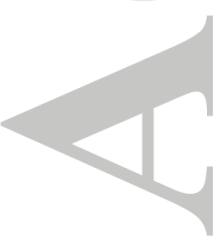

This article is protected by copyright. All rights reserved. 


\section{Conclusion}

We have described here the key characteristics of complicated meconium ileus, as distinct from simple MI, seen on fetal MRI in our cohort, and have suggested the potential of prenatal MR imaging to improve prenatal counseling and surgical planning. Fetal MRI should be considered in the diagnostic algorithm of any pregnancy in which meconium ileus is suspected, in order to aid with family preparation, better risk stratify patients, and to help avoid unnecessary delay in neonatal surgical repair.

\section{References}

1. Bales C, Liacouras CA. Intestinal Atresia, Stenosis, and Malrotation. In: Kliegman RM, Stanton BF, St Geme JW, Schor NF, editors. Nelson Textbook of Pediatrics. 20th ed. Elsevier; 2016. p. 1800-4.

2. Paradiso VF, Briganti V, Oriolo L, Coletta R, Calisti A. Meconium obstruction in absence of cystic fibrosis in low birth weight infants: An emerging challenge from increasing survival. Ital J Pediatr. 2011;37(1):55.

3. Gorter RR, Karimi A, Sleeboom C, Kneepkens CMF, Heij HA. Clinical and genetic characteristics of meconium ileus in newborns with and without cystic fibrosis. J Pediatr Gastroenterol Nutr. 2010 Apr;50(5):569-72.

4. Fakhoury K, Durie PR, Levison H, Canny GJ. Meconium ileus in the absence of cystic fibrosis. Arch Dis Child. 1992;67(10 SPEC NO):1204-6.

5. Fuchs JR, Langer JC. Long-term Outcome After Neonatal Meconium Obstruction. Pediatrics. 1998;101(4):e7-e7.

6. Rescorla FJ, Grosfeld JL, West KJ, Vane DW. Changing Patterns of Treatment and Survival in Neonates With Meconium Ileus. Arch Surg. 1989 Jul 1;124(7):837-40.

7. Ruiz MJ, Thatch KA, Fisher JC, Simpson LL, Cowles RA. Neonatal outcomes associated with intestinal abnormalities diagnosed by fetal ultrasound. J Pediatr Surg. 2009 Jan;44(1):71-5.

8. Pugash D, Brugger PC, Bettelheim D, Prayer D. Prenatal ultrasound and fetal MRI: The comparative value of each modality in prenatal diagnosis. Eur J Radiol. 2008 Nov;68(2):21426.

9. Norton M. Callen's Ultrasonography in Obstetrics and Gynecology. 6th ed. Elsevier; 2008. 225-266 p.

10. Russell SA. Textbook of Fetal Abnormalities. 3rd ed. Textbook of Fetal Abnormalities. Churchill Livingstone; 2007. 95-141 p.

11. Gupta P, Sharma R, Kumar S, Gadodia A, Roy KK, Malhotra N, et al. Role of MRI in fetal abdominal cystic masses detected on prenatal sonography. Arch Gynecol Obstet. 2010 Mar $12 ; 281(3): 519-26$.

12. Benson CB, Doubilet PM. The history of imaging in obstetrics. Radiology. 2014 Nov 23;273(2 Suppl):S92-110.

13. Quinn TM, Hubbard AM, Adzick NS. Prenatal magnetic resonance imaging enhances fetal diagnosis. J Pediatr Surg. 1998;33(4):553-8.

14. Prayer D, Brugger PC, Krampl E, Prayer L. Indikationen zur fetalen 
magnetresonanztomographie. Radiologe. 2006 Feb;46(2):98-104.

15. Mattison DR, Angtuaco T. Magnetic Resonance Imaging in Prenatal Diagnosis. Clin Obstet Gynecol. 1988;31(2):353-89.

16. Kok RD, De Vries MM, Heerschap A, Van Den Berg PP. Absence of harmful effects of magnetic resonance exposure at $1.5 \mathrm{~T}$ in utero during the third trimester of pregnancy: $\mathrm{A}$ follow-up study. Magn Reson Imaging. 2004 Jul;22(6):851-4.

17. Bulas D, Levine D, Barth R, Cassady C. ACR-SPR Practice Parameter for the safe and optimal performance of fetal MRI. Vol. 1076, American College of Radiology. 2015.

18. Ray JG, Vermeulen MJ, Bharatha A, Montanera WJ, Park AL. Association between MRI exposure during pregnancy and fetal and childhood outcomes. JAMA - J Am Med Assoc. 2016 Sep 6;316(9):952-61.

19. Huisman TAGM, Kellenberger CJ. MR imaging characteristics of the normal fetal gastrointestinal tract and abdomen. Eur J Radiol. 2008;65(1):170-81.

20. Brugger PC, Prayer D. Fetal abdominal magnetic resonance imaging. Eur J Radiol. 2006 Feb;57(2):278-93.

21. Inaoka T, Sugimori H, Sasaki Y, Takahashi K, Sengoku K, Takada N, et al. VIBE MRI for evaluating the normal and abnormal gastrointestinal tract in fetuses. Am J Roentgenol. 2007 Dec 23;189(6):1316.

22. Zizka J, Elias $\mathrm{P}$, Hodik K, Tintera J, Juttnerova V, Belobradek Z, et al. Liver, meconium, haemorrhage: The value of T1-weighted images in fetal MRI. Pediatr Radiol. 2006 Aug 24;36(8):792-801.

23. Saguintaah M, Couture A, Veyrac C, Baud C, Quere MP. MRI of the fetal gastrointestinal tract. Pediatr Radiol. 2002 Jun 16;32(6):395-404.

24. Veyrac C, Couture A, Saguintaah M, Baud C. MRI of fetal GI tract abnormalities. Abdom Imaging. 2004 Jul 12;29(4):411-20.

25. Manganaro L, Saldari M, Bernardo S, Vinci V, Aliberti C, Sollazzo P, et al. Role of magnetic resonance imaging in the prenatal diagnosis of gastrointestinal fetal anomalies. Radiol Medica. 2015 Apr 28;120(4):393-403.

26. Furey EA, Bailey AA, Twickler DM. Fetal MR Imaging of Gastrointestinal Abnormalities. RadioGraphics. 2016;36(3):904-17.

27. Martin C, Darnell A, Escofet C, Duran C, Pérez V. Fetal MR in the evaluation of pulmonary and digestive system pathology. Insights Imaging. 2012 Jun;3(3):277-93.

28. Farhataziz N, Engels JE, Ramus RM, Zaretsky M, Twickler DM. Fetal MRI of urine and meconium by gestational age for the diagnosis of genitourinary and gastrointestinal abnormalities. Am J Roentgenol. 2005 Jun 23;184(6):1891-7.

29. Casaccia G, Trucchi A, Spirydakis I, Giorlandino C, Aite L, Capolupo I, et al. Congenital intestinal anomalies, neonatal short bowel syndrome, and prenatal/neonatal counseling. J Pediatr Surg. 2006 Apr;41(4):804-7.

30. Karimi A, Gorter RR, Sleeboom C, Kneepkens CMF, Heij HA. Issues in the management of simple and complex meconium ileus. Pediatr Surg Int. 2011 Sep 22;27(9):963-8.

31. Mushtaq I, Wright VM, Drake DP, Mearns MB, Wood CBS. Meconium ileus secondary to cystic 
fibrosis. The East London experience. Pediatr Surg Int. 1998 Jun 25;13(5-6):365-9.

32. Miro J, Bard H. Congenital atresia and stenosis of the duodenum: The impact of a prenatal diagnosis. Am J Obstet Gynecol. 1988 Mar;158(3 PART 1):555-9.

33. Grzybowski S, Stoll K, Kornelsen J. The outcomes of perinatal surgical services in rural British Columbia: a population-based study. Can J Rural Med. 2013;18(4):123-9.

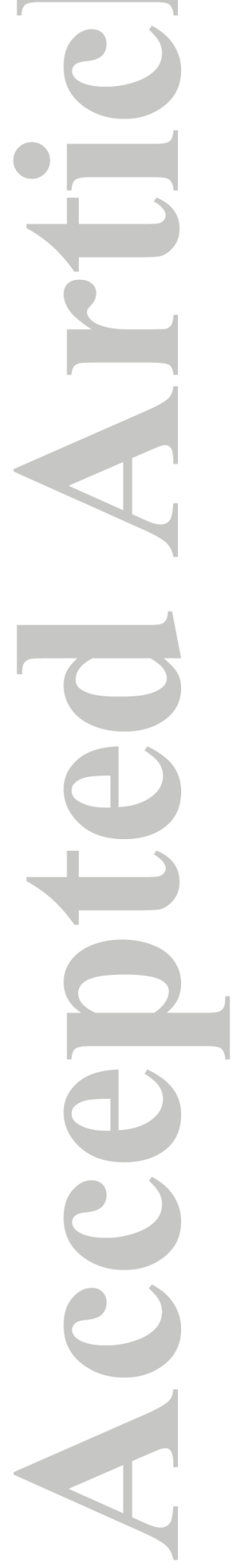



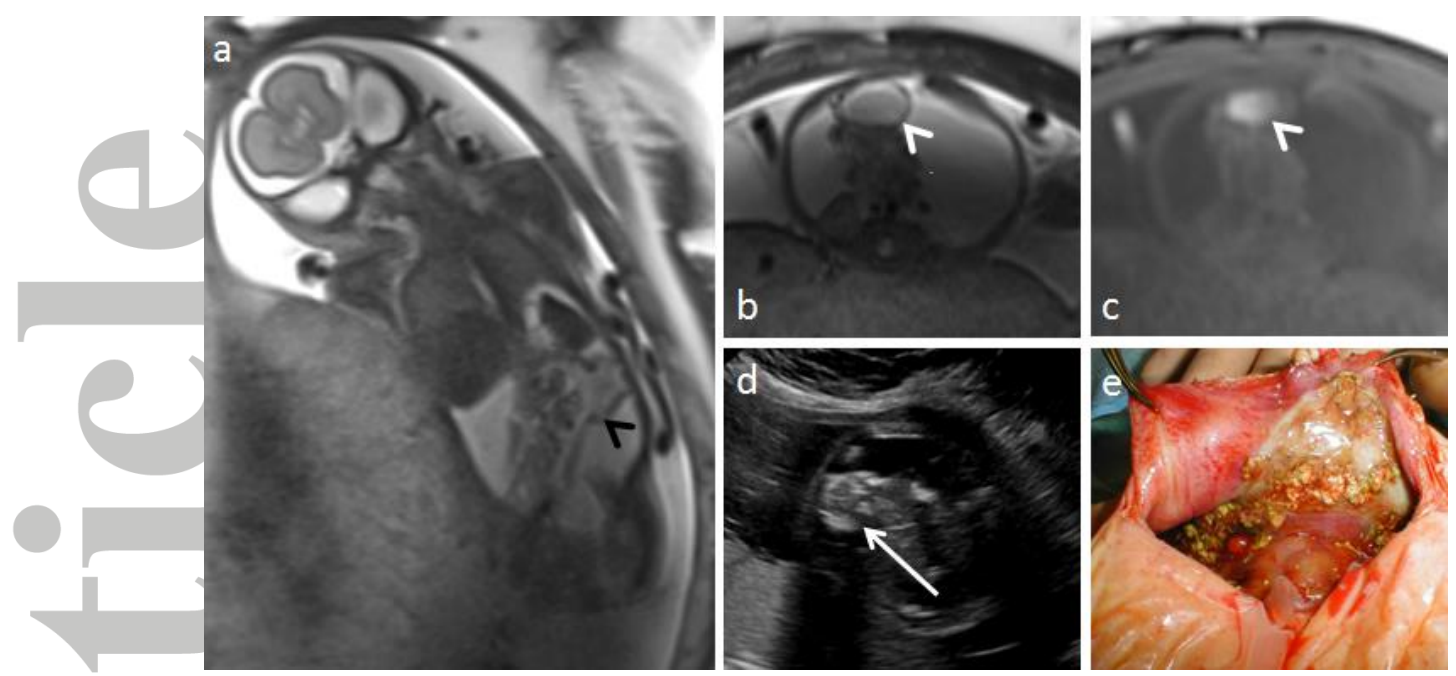

Figure 1a-e. (a) Coronal MR SSFSE image from case 1 demonstrates large volume ascites and microcolon (black arrowhead), (b) meconium pseudocyst with gradient appearance of internal contents (white arrowheads) on SSFSE (b) and T1 (c) weighted imaging. (d) US image shows echogenic appearance of the pseudocyst with posterior shadowing (white arrow), compatible with calcification, which was ultimately confirmed on surgery (e).

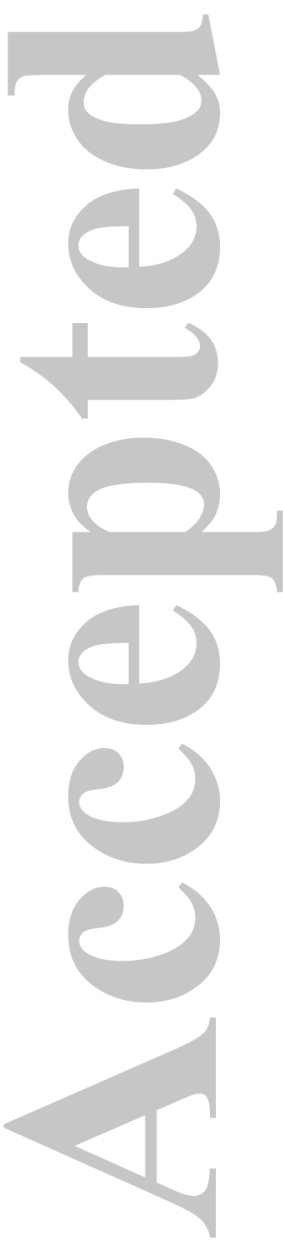

This article is protected by copyright. All rights reserved. 

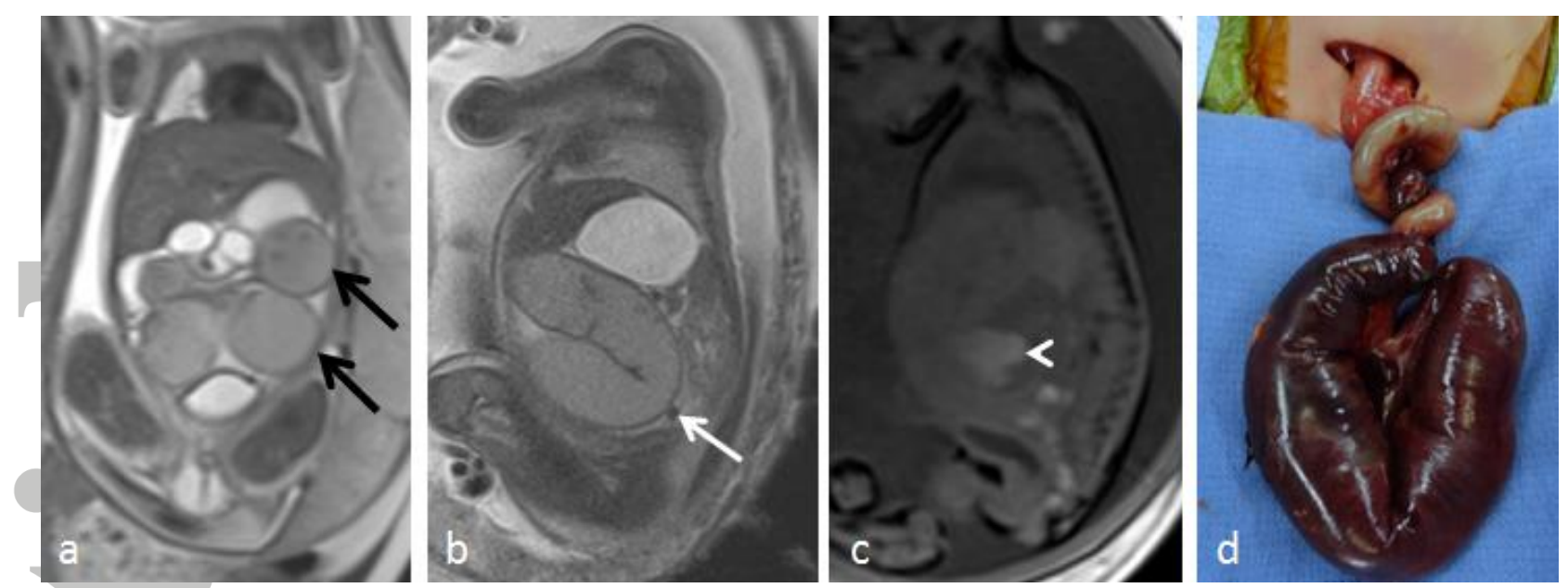

Figure 2a-d. (a) Coronal SSFSE image from case 4 demonstrating severely dilated loops of bowel (black arrows) in a configuration suggestive of volvulus. (b) Sagittal SSFSE image showing focally dilated loop of bowel accompanied by microcolon (white arrow). (c) Focal collection of meconium with gradient appearance of internal contents (white arrowhead) on sagittal T1-weighted image. (d) Surgical image of meconium ileus with volvulus.

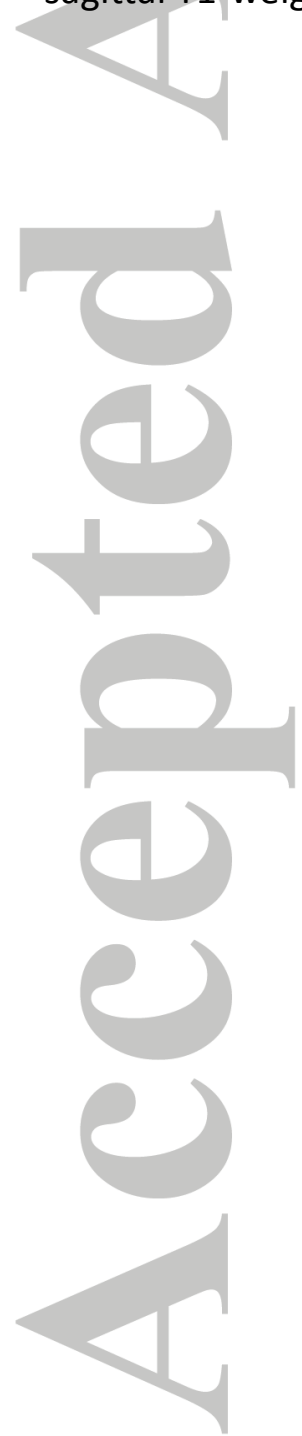




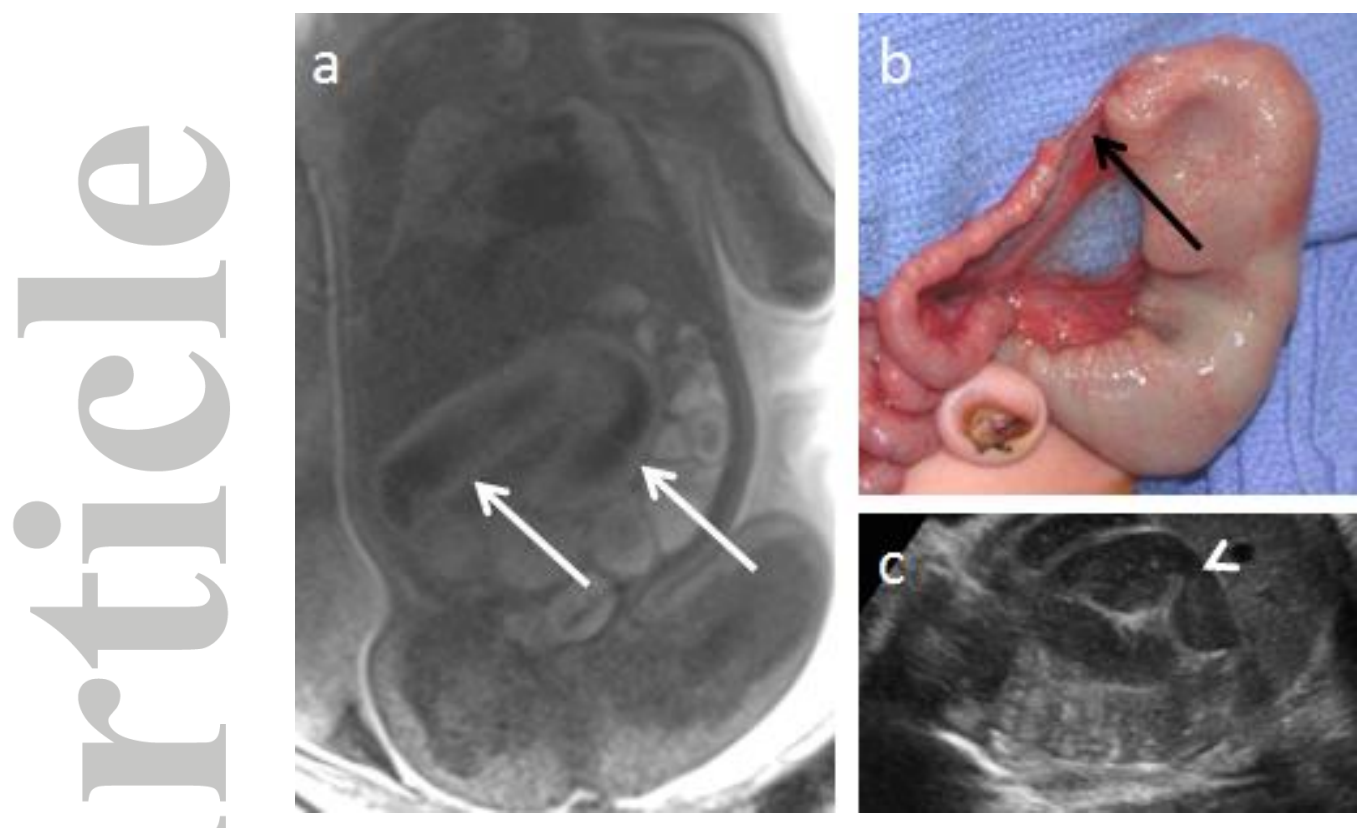

Figure 3a-c. (a) Coronal SSFSE image from case 5 demonstrates dilated loops of bowel with gradient appearance of intraluminal material (white arrows), suggesting "settling" of static bowel contents. (b) Surgical image of meconium ileus with atresia and obstruction (black arrow). (c) Longitudinal US image showing dilated bowel (white arrowhead).

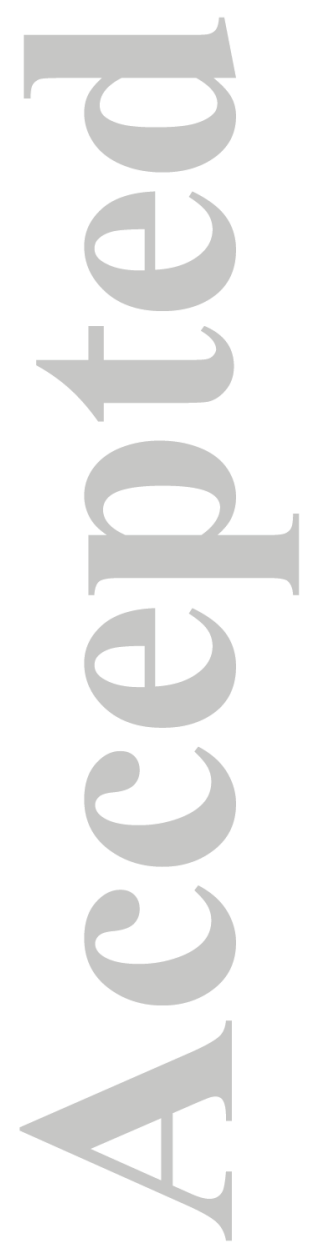

This article is protected by copyright. All rights reserved. 


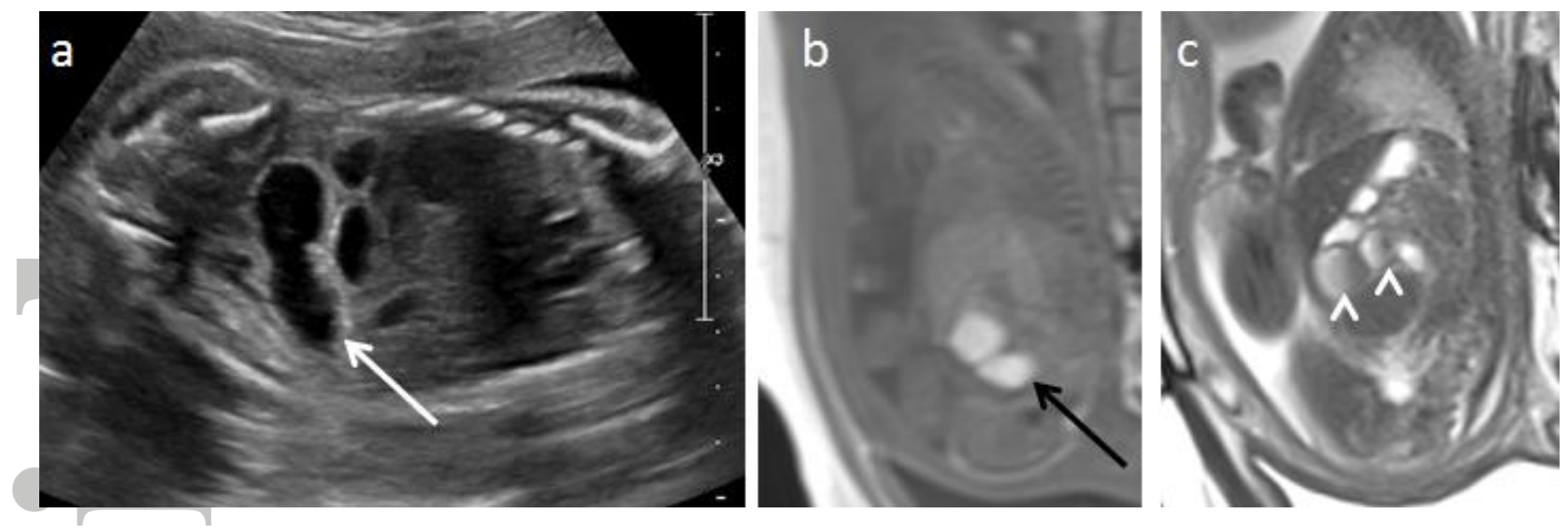

Figure 4a-c. (a) Longitudinal US image from case 6, demonstrating focally dilated loops of bowel. (b) Sagittal T1-weighted MR image showing focal collection of meconium (black arrow). (c) Sagittal SSFP MR image showing gradient appearance of intraluminal contents (white arrowheads).
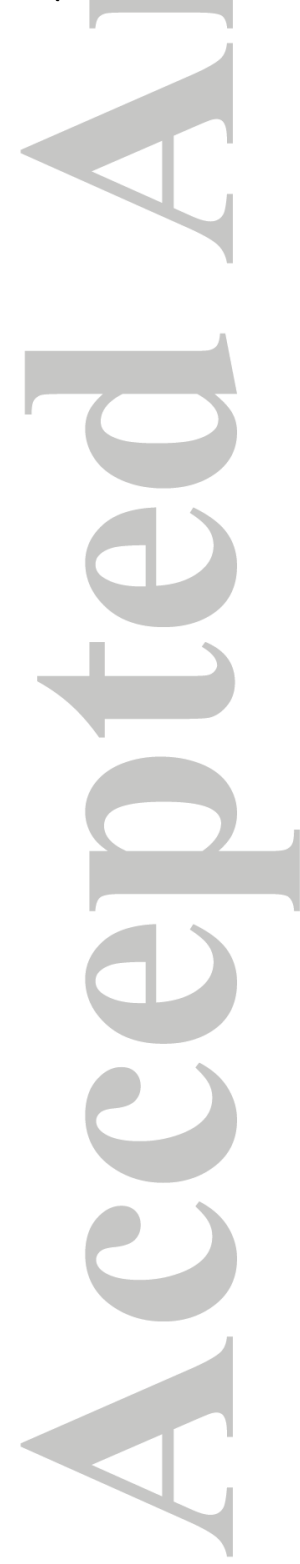

This article is protected by copyright. All rights reserved. 


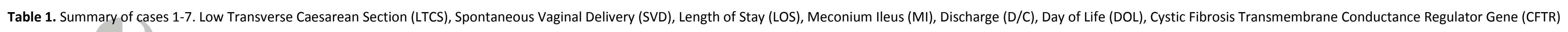

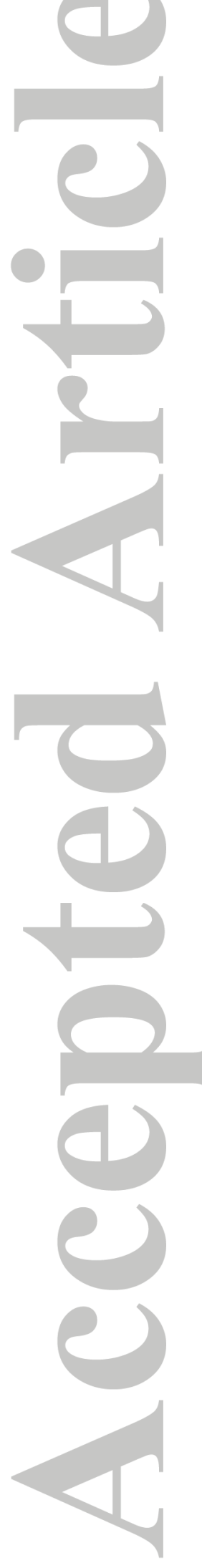

\begin{tabular}{|c|c|c|c|c|c|c|c|c|c|c|c|c|c|c|}
\hline Patient & $\begin{array}{l}\text { Maternal } \\
\text { Status }\end{array}$ & $\begin{array}{l}\text { US method } \\
\text { and GA @ } \\
\text { US (wks) }\end{array}$ & $\begin{array}{l}\text { Ultrasound (US) } \\
\text { Results }\end{array}$ & $\begin{array}{c}\text { GA @ MRI } \\
\text { (wks) }\end{array}$ & $\begin{array}{l}\text { MRI Findings } \\
\text { of complicated MI }\end{array}$ & $\begin{array}{l}\text { GA@ } \\
\text { birth } \\
\text { (wks) }\end{array}$ & Delivery & $\begin{array}{c}\text { Apgar } \\
(1,5,10 \\
\text { min) }\end{array}$ & $\begin{array}{c}\text { Los } \\
\text { (days) }\end{array}$ & $\begin{array}{l}\text { Surgical } \\
\text { repair }\end{array}$ & $\begin{array}{l}\text { Surgical } \\
\text { Diagnosis }\end{array}$ & $\begin{array}{l}\text { Pathology } \\
\text { Diagnosis }\end{array}$ & Disposition & $\begin{array}{c}\text { CFTR } \\
\text { mutation }\end{array}$ \\
\hline 1 & $\begin{array}{c}\begin{array}{c}\text { 30yo } \\
\text { G3P1011 }\end{array}\end{array}$ & 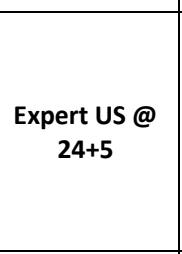 & $\begin{array}{l}\text { Massive fetal } \\
\text { abdominal } \\
\text { ascites } \\
\text { suspected bowel } \\
\text { perforation, and } \\
\text { elevated liver } \\
\text { position }\end{array}$ & 25 & $\begin{array}{c}\text { Focal Meconium } \\
\text { Intraluminal Layering } \\
\text { Microcolon } \\
\text { Bowel Perforation }\end{array}$ & $35+3$ & LTCS & $5,6,7$ & 21 & $\begin{array}{c}\text { Small } \\
\text { bowel } \\
\text { resection } \\
\text { x2 }\end{array}$ & $\begin{array}{l}\text { Meconium } \\
\text { peritonitis }\end{array}$ & $\begin{array}{l}\text { Meconium } \\
\text { pseudocyst }\end{array}$ & $\begin{array}{l}\text { D/C on full } \\
\text { PO } \\
\text { Well at one- } \\
\text { month }\end{array}$ & No \\
\hline 2 & 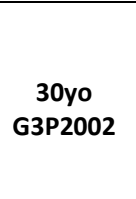 & $\underset{35}{\text { Expert US @ }}$ & $\begin{array}{l}\text { Dilated fetal } \\
\text { bowel }\end{array}$ & 35 & $\begin{array}{l}\text { Intraluminal Layering } \\
\text { Microcolon }\end{array}$ & $39+3$ & $\begin{array}{l}\text { Classic } \\
\text { cs }\end{array}$ & $1,3,3$ & 88 & $\begin{array}{c}\text { Small } \\
\text { bowel } \\
\text { resection }\end{array}$ & $\begin{array}{c}\text { Ileal atresia, } \\
\text { volvulus, } \\
\text { perforation } \\
\text { and meconium } \\
\text { peritonitis }\end{array}$ & $\begin{array}{c}\text { Ileal atresia, } \\
\text { volvulus, and } \\
\text { perforation } \\
\text { with } \\
\text { adhesions }\end{array}$ & $\begin{array}{l}\text { D/C on full } \\
\quad \text { PO } \\
\text { J-tube feeds } \\
\text { at } 11 \text { months }\end{array}$ & Yes \\
\hline 3 & $\begin{array}{c}\text { 30yo } \\
\text { G5P4004 }\end{array}$ & $\begin{array}{c}\text { Routine US } \\
@ 18\end{array}$ & $\begin{array}{l}\text { Fetal echogenic } \\
\text { bowel }\end{array}$ & 27 & $\begin{array}{l}\text { Focal Meconium } \\
\text { Intraluminal layering } \\
\text { Microcolon }\end{array}$ & 40 & SVD & $8,6,9$ & 160 & $\begin{array}{c}\text { Small } \\
\text { bowel } \\
\text { resection }\end{array}$ & $\begin{array}{l}\text { Small bowel } \\
\text { atresia and } \\
\text { volvulus }\end{array}$ & $\begin{array}{c}\text { Transmural } \\
\text { necrosis of } \\
\text { small bowel } \\
\text { suggesting } \\
\text { perforation }\end{array}$ & $\begin{array}{c}\text { D/C on PO + } \\
\text { TPN } \\
\text { Regular diet } \\
\text { @ 6mo of life }\end{array}$ & Yes \\
\hline 4 & $\begin{array}{l}20 y 0 \\
\text { G1P0 }\end{array}$ & $\begin{array}{c}\begin{array}{c}\text { Routine US } \\
@ 33+1\end{array} \\
0\end{array}$ & $\begin{array}{l}\text { Dilated fetal } \\
\text { bowel }\end{array}$ & $33+2$ & $\begin{array}{l}\text { Focal Meconium } \\
\text { Intraluminal layering } \\
\text { Microcolon }\end{array}$ & $33+6$ & LTCS & 5,8 & 117 & $\begin{array}{c}\text { Small } \\
\text { bowel } \\
\text { resection }\end{array}$ & $\begin{array}{l}\text { Small bowel } \\
\text { volvulus, } \\
\text { ischemia, and } \\
\text { perforation }\end{array}$ & $\begin{array}{c}\text { Transmural } \\
\text { necrosis and } \\
\text { hemorrhagic } \\
\text { mesentery }\end{array}$ & No follow-up & Yes \\
\hline 5 & $\begin{array}{c}\begin{array}{c}\text { 30yo } \\
\text { G3P1011 }\end{array}\end{array}$ & $\begin{array}{c}\text { Expert us @ } \\
36+2\end{array}$ & $\begin{array}{l}\text { Dilated fetal } \\
\text { bowel }\end{array}$ & $37+2$ & $\begin{array}{l}\text { Intraluminal Layering } \\
\text { Microcolon }\end{array}$ & $37+6$ & SVD & 8,9 & 13 & $\begin{array}{l}\text { Resection } \\
\text { of terminal } \\
\text { ileum and } \\
\text { cecum }\end{array}$ & $\begin{array}{l}\text { Ileal atresia } \\
\text { and meconium } \\
\text { peritonitis }\end{array}$ & $\begin{array}{l}\text { Small bowel } \\
\text { atresia and } \\
\text { evidence of } \\
\text { perforation }\end{array}$ & $\begin{array}{c}\text { D/C on full } \\
\text { PO } \\
\text { Doing well @ } \\
\text { 9mo of life }\end{array}$ & No \\
\hline 6 & $\begin{array}{l}36 y 0 \\
\text { G1PO }\end{array}$ & 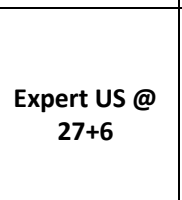 & $\begin{array}{l}\text { Dilated fetal } \\
\text { bowel }\end{array}$ & $28+3$ & $\begin{array}{l}\text { Focal Meconium } \\
\text { Intraluminal Layering } \\
\text { Microcolon }\end{array}$ & 30 & $\begin{array}{l}\text { Classical } \\
\text { cs }\end{array}$ & $8,7,9$ & N/A & $\begin{array}{l}15 \mathrm{~cm} \\
\text { resection } \\
\text { of jejunum }\end{array}$ & Jejunal atresia & $\begin{array}{c}\text { Small bowel } \\
\text { stenosis and } \\
\text { dilated glands } \\
\text { of inspissated } \\
\text { meconium }\end{array}$ & $\begin{array}{c}\text { TPN } \\
\text { dependent as } \\
\text { of DOL17 }\end{array}$ & No \\
\hline 7 & 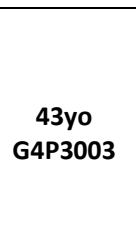 & $\begin{array}{c}\begin{array}{c}\text { Routine US } \\
@ 30+4\end{array} \\
0\end{array}$ & $\begin{array}{l}\text { Dilated fetal } \\
\text { bowel and } \\
\text { ascites }\end{array}$ & $31+3$ & $\begin{array}{l}\text { Focal Meconium } \\
\text { Intraluminal Layering } \\
\text { Microcolon } \\
\text { Bowel Perforation }\end{array}$ & $32+3$ & SVD & N/A & N/A & N/A & N/A & $\begin{array}{c}\text { Meconium } \\
\text { peritonitis } \\
\text { and } \\
\text { perforation at } \\
\text { ileocecal } \\
\text { junction }\end{array}$ & N/A & Unknown \\
\hline
\end{tabular}

